\title{
STUDIES ON THE IMPACT OF WORK FROM HOME DURING COVID-19 PANDEMIC: A SYSTEMATIC LITERATURE REVIEW
}

\author{
${ }^{1}$ Nur Ain Alifuddin \\ ${ }^{2}$ Dzurizah Ibrahim \\ Faculty of Social Sciences and Humanities \\ University Malaysia Sabah \\ 1annally94@gmail.com \\ 2idzuri@ums.edu.my \\ Tarikh dihantar: 15 Mac 2021 / Tarikh diterima: 29 Mei 2021
}

\begin{abstract}
When the pandemic outbreak happened back in the year 2020, the Government and the policymakers took preventive steps and directive measures to sustain social movement and infection among the citizens. Common action that has been taken globally was the implementation of lockdown. Consequently, non-essential businesses or organizations had to resolve to transition from central office to work-from-home for as long as the lockdown period ended. This has brought a greater change in the world of work and boosted the experimentation of work-from-home arrangements worldwide. Despite it being a practice that some may have experienced before, it is still relatively uncommon and unusual to be done on such a large scale for some countries. Therefore, many are interested to see the outcome of work-from-home, the impact it had on employers, employees, and companies. However, the ample amount of works of literature made it hard to distinguish the direction and trend of this research. This paper aims to identify and highlight the major findings on the impacts of work-from-home by reviewing 55 published papers in the year between 2020 to 2021 and analyze them through a thematic analysis. The results show 60 percent of these studies are covered by the field of social sciences which both involve developed and developing countries. Nevertheless, the impact of workfrom-home was found common as the problem used to arise even before the pandemic happened. This gives an opportunity in future studies to finally resolve some of these problems if work-from-home soon becomes the 'new norm' in the world of work.
\end{abstract}

Keywords: Work from home; Remote Working, Telework, Flexible working arrangement; Systematic Literature Review; COVID-19

\section{INTRODUCTION}

Covid-19 is a contagious communicable disease. The World Health Organization (WHO) (2021) explains that it can spread, primarily, from droplets of saliva or discharge from people who were infected. When the person coughs or sneezes, there is a high risk of the virus getting caught onto the surface and infecting another person (WHO, 2021). Preventive measures must be taken to contain this from getting out of control through social distancing, quarantines, lockdown, restrictions, and closed borders. When the primary report of a brand-new virus appears back in Wuhan, China in 2019, the world is not prepared for how destructive it can be to our world crisis today. As of 26 March 2021, there are 125,160,255 confirmed cases of infection and a couple of 2,748,737 deaths recorded and reported to the World Health Organization (WHO,2021). This exponential growth has caused mass panic and fear around the world; it also puts public health under extreme pressure to constrain and control the spread. Demands for ventilators and protective personal equipment (PPE) become critically high and a few countries and states undergo shortages of those medical supplies (Lee et. al.,2020).

However, health crises are not the sole problem that arises during these trying times; the economy, financial markets, and labor face consequences following the actions taken by the State and public health. Pak et. al. (2020) mentioned that the reductions in income, the increase of unemployment, disruptions of transportations, service, production, and 
manufacturing companies are only some of those stricken by preventive measures. It made everyone wonder if there is more underlying impact coming to light during this unfolding crisis. Essential and non-essential service has become the sole focus for policymakers; non-essential services alternative plans were to work from home during the lockdown and not many can guess for how long that this adjustment goes to be for their career. Economic conditions have swiftly shown their negative impact by these steps and workplace absenteeism is not far along from this (Pak et. al., 2020). Concern for the quality of jobs is guaranteed to come during these situations since this can be visiting effect in the long run for labor and its development, and also the uncertainty around the flexible working arrangement from office to work from home still remains; thus, could stir different opinions among scholars, academics, policymakers, and therefore the public themselves, since the effectiveness of recommended action continues to be unclear.

With this knowledge easily obtained through the reliable database on the web, this has allowed us to select out from a spread of disciplines like psychology, social science, economics, finance, and business to get a relevant or relatable answer to our questions; what is the impact of work-from-home? Therefore, we apply a systematic literature review approach to gather mass information and choose several works of literature that have some significance and evidence to the subject discussed. It absolutely was known to produce the foremost comprehensive data collection for the knowledge to own more quality and validity. Although systematic literature review is time-consuming and wants a proper search protocol, this mass information at hand can often be confusing, and narrowing it right down to collect information might just help in answering our questions. By generating a summary of impacts on working from home, this article may help researchers to guide them in future studies within the context that arise within the data. Hence, open a chance on investigating more thoroughly the constraints of the present studies. This investigation was mapped to understand the situations and enable open discussion for better outcomes in work relations.

\section{METHODS}

A literature review has always been deemed essential in any research. It is considered as the fundamental step in obtaining knowledge of our topic of interest or research questions. In the preliminary research on the impact of work from home on the database, we found there are masses of research done under that trend but there are also unrelated issues attached to it. According to Xiao and Watson (2017), what researchers always lack is rigorous systematic reviews. Traditional reviews which are often used by researchers lack thoroughness and rigor, hence, raise the questions of the quality and its frontier knowledge (Snyder, 2019). Therefore, by doing the systematic literature review, we not only obtain transparency in our data collection but also be able to understand the depth and breadth of the existing body of literature to explore by summarizing and analyzing. Furthermore, the high-quality systematic literature review methodology has been a great contribution for policymakers and entrepreneurs (Kraus et. al., 2020).

To identify relatable literature to answer the research question, a search strategy was developed through Scopus, ScienceDirect, Emerald, Elsevier, Google Scholar, and Sage Publication. The databases are popular among academics and researchers alike. Boolean Operator was used to guiding the search terms such as 'flexible working arrangement', 'work from home', and 'telework'. The search strategy only spanned from 2020 to 2021 works of literature and it includes articles, article notes, and discussion papers. There is no specific country to choose from since this article is open to any specific area. When it comes to systematic literature review methodology; the better procedure in guiding the selection process is through PRISMA which is introduced by Moher et. al. (2009). The selection is focused on 
the subject area of Social Sciences, Business, Environmental Science, Economics, and Psychology which resulted in 340 studies. The next phase included looking through the title and abstract independently and excluded any literature that does not fit the topic research. Furthermore, since this study is under a restricted budget, any literature that was not open to access was also excluded from the selection process. It resulted in 164 studies selected with 176 research articles excluded.

Consequently, the selection began through the title and abstracts of its publications, both were evaluated independently. Therefore, the publication was excluded when it met this criterion, such as written in other languages (other than English), not relevant to the topic discussed, type of paper such as; news article, reports and dissertations, and publication that was not in line with the main questions of this study. 102 studies made it through this phase while 62 studies were excluded. Then, the 102 studies go through the screening process, wherein in this phase, we read through the full text and search potentially for the relevant information to the topics discussed. Several kinds of literature did not focus on the flexible working arrangement; thus, their information was not able to show the impacts in what we were investigating. This caused 47 more studies to be excluded while the other 55 studies made it through the extraction phase. This procedure can easily be understood in figure 1 .

After the selection process which includes extraction and inclusion, we were able to obtain 55 works of literature to be analyzed through thematic synthesis. Thematic analysis is known to help in extracting information from the literature to synthesize it into an analytical theme. It is suitable in answering our specific question as suggested by Thomas and Harden (2008).

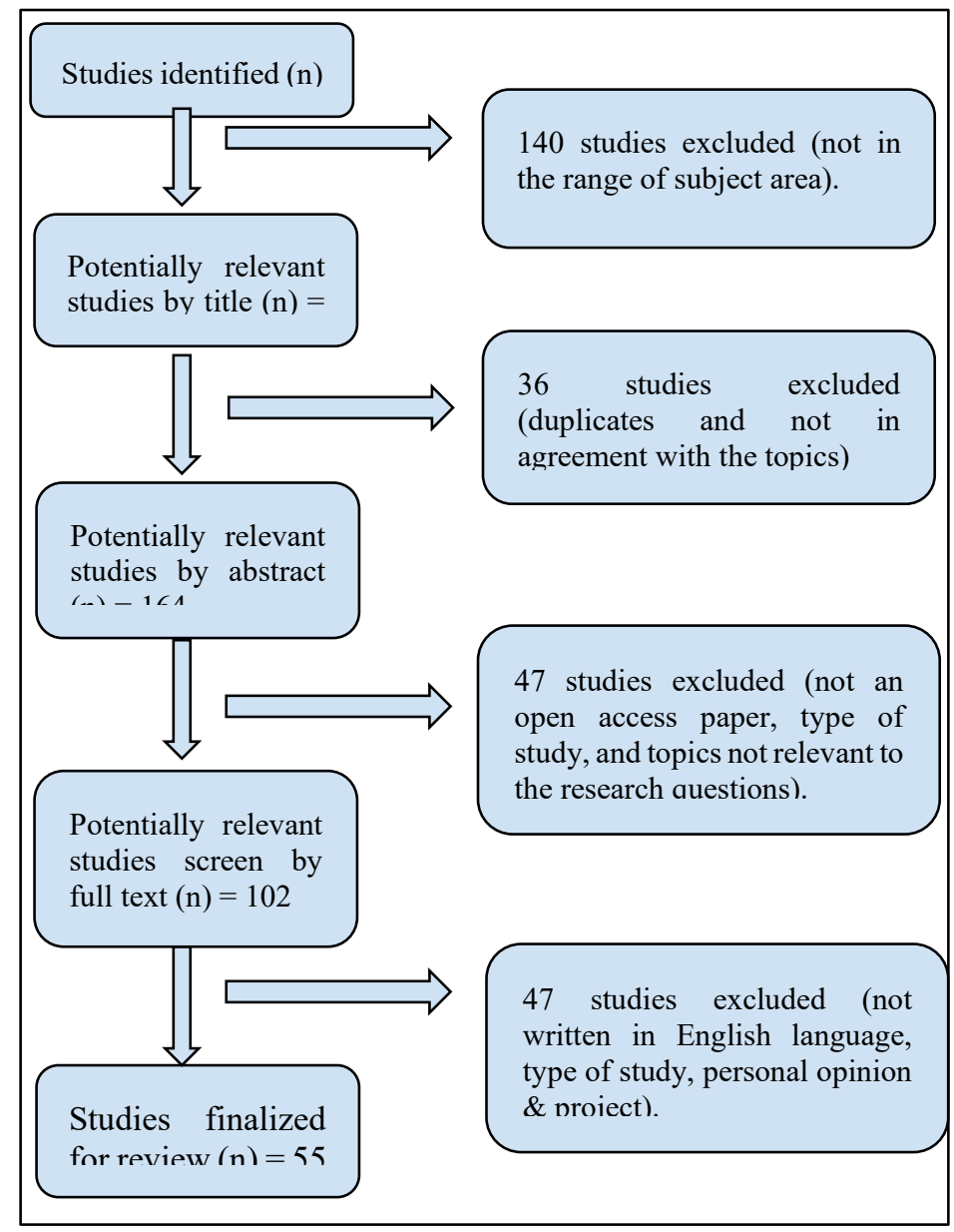

Figure 1 Procedure for systematic literature review 


\section{RESULTS AND DISCUSSION}

When it comes to publication data, ever since the beginning of pandemic breakout and international lockdown implemented worldwide or globally, many researchers took the opportunity to start investigating issues that arise from such circumstances in the year 2020 . This shows how aware of current literature in the changes that transform the world of work. As illustrated in Table 1, also covers most social science disciplines with private sectors having the highest rate in population coverage.

Table 1 Study Characteristic

\begin{tabular}{|lc|}
\hline Study characteristic & N \\
\hline Publication Data & \\
2020 & 38 \\
2021 & 17 \\
& \\
Countries & \\
Developed & 7 \\
Developing & 3 \\
Non-specific & 6 \\
& \\
Subject Area & \\
Economic \& Businesses & 5 \\
Psychology & 10 \\
Social Science & 32 \\
& \\
Sample/Population & 14 \\
Private Sectors & 11 \\
Public Sectors & 5 \\
Dual-career Families & \\
\hline
\end{tabular}

Looking through the article that was reviewed, there is an ample amount of information regarding the impacts from different researchers with various backgrounds in subject areas. Nevertheless, this information is assembled into ten themes with major findings presented and discussed to better highlight the direction of this trend. 
Table 2 Summary of Literature on Impact of Work from Home (WFH)

Theme 1: Impact in Working Hours

\begin{tabular}{|c|c|c|c|c|c|}
\hline No. & $\begin{array}{c}\text { Author } \\
\text { (year) }\end{array}$ & Country & Research Design & Sample/Population & Findings \\
\hline 1. & Shibata & United States & Quantitative & Employees & $\begin{array}{l}\text { The decline in working hours has something to do with the } \\
\text { feasibility of certain occupations to work from home during the } \\
\text { lockdown. }\end{array}$ \\
\hline 2. & $\begin{array}{l}\text { Alipour et. al. } \\
(2021)\end{array}$ & Germany & Quantitative & Industrial companies and firms & $\begin{array}{l}\text { Work from home has protected the employees from reduction in } \\
\text { working hours, therefore, they won't be concerned with job } \\
\text { insecurity. }\end{array}$ \\
\hline 3. & $\begin{array}{l}\text { Casele \& } \\
\text { Posel }(2021)\end{array}$ & South Africa & Quantitative & Adult & $\begin{array}{l}\text { Due to the job loss South Africa sees a decline in working hours } \\
\text { and this includes those who remain employed. }\end{array}$ \\
\hline 4. & $\begin{array}{l}\text { Schall et. al. } \\
(2020)\end{array}$ & - & Quantitative & Employees (IDD) & $\begin{array}{l}\text { The transition to work from home has made employees } \\
\text { experiencing reduction in working hours and furlough/layoff. }\end{array}$ \\
\hline
\end{tabular}

Table 3 Summary of Literature on Impact of Work from Home (WFH)

Theme 2: Impact in Employment Relations

\begin{tabular}{|c|c|c|c|c|c|}
\hline No. & $\begin{array}{c}\text { Author } \\
\text { (year) }\end{array}$ & Country & Research Design & Sample/Population & Findings \\
\hline 1. & $\begin{array}{l}\text { Jackowska \& } \\
\text { Lauring } \\
(2021)\end{array}$ & Denmark & Quantitative & Multinational organizations & $\begin{array}{l}\text { Despite virtual meetings allowing employees to communicate } \\
\text { with one another, the lack of trust can make them question their } \\
\text { co-workers' efficiency. }\end{array}$ \\
\hline 2. & $\begin{array}{l}\text { Waizenegger } \\
\text { et. al. }(2020)\end{array}$ & - & Qualitative & Employees & $\begin{array}{l}\text { The lack of face to face meetings reduces some common work } \\
\text { culture such as ad-hoc conversation and its occurrence when } \\
\text { working from home. }\end{array}$ \\
\hline 3. & $\begin{array}{l}\text { Prihadi et. al. } \\
(2020)\end{array}$ & Malaysia & Quantitative & Urban employees & $\begin{array}{l}\text { Working from home has an effect on employees' efficiency and } \\
\text { they are in a social isolation due to the restriction in } \\
\text { lockdown/policy. Nevertheless, the advancement of } \\
\text { digitalization may help them to be out of the alienation since it } \\
\text { made it possible to connect with colleagues. }\end{array}$ \\
\hline 4. & $\begin{array}{l}\text { Osman et. al. } \\
(2020)\end{array}$ & Malaysia & Quantitative & $\begin{array}{l}\text { Employees (public/private } \\
\text { sectors) }\end{array}$ & $\begin{array}{l}\text { There is a positive impact on employment relations if there is peer } \\
\text { support to boost employees' motivation. }\end{array}$ \\
\hline
\end{tabular}


Table 4 Summary of Literature on Impact of Work from Home (WFH)

Theme 3: Impact in Gender Division

\begin{tabular}{|c|c|c|c|c|c|}
\hline No. & $\begin{array}{c}\text { Author } \\
\text { (year) }\end{array}$ & Country & Research Design & Sample/Population & Findings \\
\hline 1. & $\begin{array}{l}\text { Yaish et. al. } \\
(2021)\end{array}$ & Israel & Quantitative & Employed and self-employed & $\begin{array}{l}\text { During the lockdown, it is found that women have an increase in } \\
\text { the demands of housework than men and they generally had to do } \\
\text { more unpaid work during the unprecedented times. }\end{array}$ \\
\hline 2. & $\begin{array}{l}\text { Bhattacharjee } \\
(2020)\end{array}$ & India & Mixed methods & Women employees & $\begin{array}{l}\text { The domestic work has been taken mostly by women and they } \\
\text { had a hard time doing it since most of them could not ask for a } \\
\text { helper such as a maid or a nanny to share those responsibilities. }\end{array}$ \\
\hline 3. & $\operatorname{Lim}_{(2020)}$ et. al. & South Korea & Quantitative & $\begin{array}{l}\text { Registered participants in } \\
\text { Hankook Research }\end{array}$ & $\begin{array}{l}\text { Even though there is a small chance for a balanced gender } \\
\text { division between men and women in doing both paid work and } \\
\text { housework. The young are skeptical of such ideas since, in the } \\
\text { end, women will be carrying those burdens or responsibilities. }\end{array}$ \\
\hline 4. & $\begin{array}{l}\text { Meyer et. al. } \\
(2021)\end{array}$ & Germany & Quantitative & Random & $\begin{array}{l}\text { Women tend to have no partner support when working from } \\
\text { home and men are less likely to receive negative impact from } \\
\text { working from home. }\end{array}$ \\
\hline 5. & $\begin{array}{l}\text { Yerkes et. al. } \\
(2020)\end{array}$ & Netherlands & Quantitative & $\begin{array}{l}\text { Employees } \\
\text { members) }\end{array}$ & $\begin{array}{l}\text { Despite mothers taking most of the domestic responsibilities, they } \\
\text { managed to prove that even fathers take a greater share of parental } \\
\text { responsibilities compared to before the pandemic happen. }\end{array}$ \\
\hline 6. & $\begin{array}{l}\text { Yaish et. al. } \\
(2021)\end{array}$ & Israel & Quantitative & Employed and self-employed & $\begin{array}{l}\text { During the lockdown, it is found that women have an increase in } \\
\text { the demands of housework than men and they generally had to do } \\
\text { more unpaid work during the unprecedented times. }\end{array}$ \\
\hline
\end{tabular}


Table 5 Summary of Literature on Impact of Work from Home (WFH)

Theme 4: Impact in Work-life Balance

\begin{tabular}{|c|c|c|c|c|c|}
\hline No. & $\begin{array}{c}\text { Author } \\
\text { (year) }\end{array}$ & Country & Research Design & Sample/Population & Findings \\
\hline 1. & $\begin{array}{l}\text { McDowell et. } \\
\text { al. }(2020)\end{array}$ & $\begin{array}{l}\text { United States of } \\
\text { America }\end{array}$ & Quantitative & 2,303 Employees & $\begin{array}{l}\text { Employees find themselves spending more time at work than } \\
\text { their sedentary activities. They have to work long hours, attend } \\
\text { online meetings occasionally and spend more time in the } \\
\text { workspace at home; which makes it work taking up more of their } \\
\text { time than even they don't have their times. }\end{array}$ \\
\hline 2. & $\begin{array}{l}\text { Fukushima } \\
\text { et. al. }(2021)\end{array}$ & Japan & Quantitative & 1,239 Metropolitan employees & $\begin{array}{l}\text { They found that work takes most of the employees' time when } \\
\text { working from home and it made them less physically active and } \\
\text { less leisure time at home. This would in turn affect their well- } \\
\text { being as well. }\end{array}$ \\
\hline 3. & $\begin{array}{l}\text { Pluut \& } \\
\text { Wonders } \\
(2020)\end{array}$ & Netherlands & Quantitative & Employees & $\begin{array}{l}\text { There is an increase in blurred work boundaries faced by } \\
\text { employees as they are more active when working from home. } \\
\text { This has the potential to make them feel exhausted or distressed. }\end{array}$ \\
\hline 4. & $\begin{array}{l}\text { Palumbo } \\
(2020)\end{array}$ & $\begin{array}{l}\text { European } \\
\text { Union, Albania, } \\
\text { Montenegro, } \\
\text { Norway, Serbia, } \\
\text { Switzerland, the } \\
\text { Former } \\
\text { Yugoslav } \\
\text { Republic of } \\
\text { Macedonia } \\
\text { (FYROM), } \\
\text { United } \\
\text { Kingdom, and } \\
\text { Turkey }\end{array}$ & Quantitative & Random & $\begin{array}{l}\text { Work from home gives a negative effect on employees as most } \\
\text { public sector employees suffer a great deal of work to life conflict } \\
\text { and work fatigue that disrupts their work-life balance. }\end{array}$ \\
\hline 5 & $\begin{array}{l}\text { Syazwani et. } \\
\text { al. }(2020)\end{array}$ & Malaysia & Quantitative & Employees (parent) & $\begin{array}{l}\text { The flexibility from working from home has given the employees } \\
\text { the balance they need between work and family. }\end{array}$ \\
\hline
\end{tabular}


Table 6 Summary of Literature on Impact of Work from Home (WFH)

Theme 5: Impact in Gender gaps/Inequality

\begin{tabular}{|c|c|c|c|c|c|}
\hline No. & $\begin{array}{l}\text { Author } \\
\text { (year) }\end{array}$ & Country & Research Design & Sample/Population & Findings \\
\hline 1. & $\begin{array}{l}\text { Feng } \\
\text { Savani } \\
(2020)\end{array}$ & $\begin{array}{l}\text { United States of } \\
\text { America }\end{array}$ & Quantitative & $\begin{array}{l}\text { Employees in dual-career } \\
\text { families }\end{array}$ & $\begin{array}{l}\text { They found that it is true there are gender gaps arising during the } \\
\text { pandemic as women had to take many responsibilities at home } \\
\text { and work more than men. Therefore, women become less } \\
\text { satisfied with their circumstances. }\end{array}$ \\
\hline
\end{tabular}

Table 7 Summary of Literature on Impact of Work from Home (WFH)

Theme 6: Impact in Job Insecurity

\begin{tabular}{|c|c|c|c|c|c|}
\hline No. & $\begin{array}{l}\text { Author } \\
\text { (year) }\end{array}$ & Country & Research Design & Sample/Population & Findings \\
\hline 1. & $\begin{array}{l}\text { Adam-Prassl } \\
\text { et. al. }(2020)\end{array}$ & $\begin{array}{l}\text { United } \\
\text { Kingdom, } \\
\text { United States of } \\
\text { America \& } \\
\text { Germany }\end{array}$ & Quantitative & $\begin{array}{l}\text { Employees with paid work in } \\
\text { the last } 12 \text { months }\end{array}$ & $\begin{array}{l}\text { It seems that those in the permanent contracts are much safer from } \\
\text { being furlough if compared to those who don't and the work } \\
\text { arrangement of work from home is not secure for those who are } \\
\text { vulnerable to being laid off. }\end{array}$ \\
\hline 2. & $\begin{array}{l}\text { Joshi et. al. } \\
(2020)\end{array}$ & India & Quantitative & $\begin{array}{l}\text { Employees from } 25 \text { to } 60 \text { years } \\
\text { old }\end{array}$ & $\begin{array}{l}\text { Due to the lack of digitalization many workers are concerned } \\
\text { about the financial loss that they have to face during lockdown } \\
\text { implementation. }\end{array}$ \\
\hline 3. & $\begin{array}{l}\text { Prochazkac } \\
\text { et. al. }(2020)\end{array}$ & $\begin{array}{l}\text { Germany, } \\
\text { Czech Republic, } \\
\text { Slovakia \& Italy }\end{array}$ & Quantitative & Random & $\begin{array}{l}\text { Employees' income was greatly affected as working from home } \\
\text { was forced on most occupations and the closure of most of the } \\
\text { economic activities. Also, many of them were not able to work } \\
\text { from home, thus, they lost social contact that related to work. }\end{array}$ \\
\hline 4. & $\begin{array}{l}\text { Forsythe et. } \\
\text { al. }(2020)\end{array}$ & $\begin{array}{l}\text { United States of } \\
\text { America }\end{array}$ & Quantitative & Random & $\begin{array}{l}\text { When work from home became the new arrangement to adapt to } \\
\text { the pandemic crisis, job postings had been put on hold to avoid } \\
\text { employers laying off their own employees. }\end{array}$ \\
\hline 5. & $\begin{array}{l}\text { Malik et. al. } \\
(2020)\end{array}$ & - & Quantitative & $\begin{array}{l}\text { Employees \& Organizations } \\
\text { (employer) }\end{array}$ & $\begin{array}{l}\text { Employees and employers are becoming more concerned of } \\
\text { social isolation, job insecurity, financial dilemma and family } \\
\text { problem as it can affect their effectiveness of working from home. }\end{array}$ \\
\hline
\end{tabular}


Table 8 Summary of Literature on Impact of Work from Home (WFH)

\begin{tabular}{|c|c|c|c|c|c|}
\hline No. & $\begin{array}{l}\text { Author } \\
\text { (year) }\end{array}$ & Country & Research Design & Sample/Population & Findings \\
\hline 1. & $\begin{array}{l}\text { Limbers et. } \\
\text { al. }(2020)\end{array}$ & $\begin{array}{l}\text { United States of } \\
\text { America }\end{array}$ & Quantitative & Full-time employees (mother) & $\begin{array}{l}\text { The parenting stress can hit the mother the hardest if there is no } \\
\text { moderate-intensity physical activities for them to maintain a good } \\
\text { well-being despite the pressure during these circumstances. }\end{array}$ \\
\hline 2. & $\begin{array}{l}\text { Anwar et. al. } \\
(2021)\end{array}$ & $\begin{array}{l}\text { Pakistan } \\
\text { Malaysia }\end{array}$ & Quantitative & Employees (white-collar) & $\begin{array}{l}\text { The lockdown has affected employees' well-being as it forces } \\
\text { them to not just stay at home but also work from home. Therefore, } \\
\text { they were deprived from having growth in work opportunities and } \\
\text { withheld communication with colleagues. }\end{array}$ \\
\hline 3. & $\begin{array}{l}\text { Molino et. al. } \\
(2020)\end{array}$ & Italy & Quantitative & Employees & $\begin{array}{l}\text { With the increase of workload when employees work from home, } \\
\text { they are occasionally having a technostress since they have to } \\
\text { work faster and longer; which in turn, shows how technology } \\
\text { invaded most of their personal life. }\end{array}$ \\
\hline 4. & $\begin{array}{l}\text { Bhumika } \\
(2020)\end{array}$ & North India & Quantitative & Employees (Professional) & $\begin{array}{l}\text { Women had experienced emotional exhaustion due to } \\
\text { interference both in work and their personal life. A participative } \\
\text { leadership might reduce this to make them able to have a healthy } \\
\text { well-being. }\end{array}$ \\
\hline 5. & Lee (2021) & Singapore & Mixed methods & $\begin{array}{l}\text { Employees (Public \& private } \\
\text { sectors) }\end{array}$ & $\begin{array}{l}\text { When working from home, employees are vulnerable to these } \\
\text { kinds of emotions; anxiety, stress, unfairness, inferiority and } \\
\text { vulnerability. }\end{array}$ \\
\hline 6. & $\begin{array}{l}\text { Kniffin et. al. } \\
(2021)\end{array}$ & Global & - & Employees & $\begin{array}{l}\text { Work from home has the potential to derange employee } \\
\text { communication which in turn leads to social isolation that can } \\
\text { have a negative effect on their psychological and mental well- } \\
\text { being. }\end{array}$ \\
\hline 7. & $\begin{array}{l}\text { Majumdar et. } \\
\text { al. (2020) }\end{array}$ & India & Quantitative & Employees (corporate sectors) & $\begin{array}{l}\text { Working from home can only mean that there is a risk of too } \\
\text { much screen exposure and some employees have experienced it, } \\
\text { which causes them sleep deprivation that has an effect on their } \\
\text { well-being. }\end{array}$ \\
\hline 8. & $\begin{array}{l}\text { Sheikh et. al. } \\
(2020)\end{array}$ & - & Quantitative & $\begin{array}{l}200 \text { Employees (25-60 years } \\
\text { old) }\end{array}$ & $\begin{array}{l}\text { Teachers that shifted to working from home and making online } \\
\text { lectures are vulnerable and having depression due to } \\
\text { responsibility between family and work. }\end{array}$ \\
\hline 9. & $\begin{array}{l}\text { Akyildiz \& } \\
\text { Durna (2020) }\end{array}$ & Turkey & Quantitative & Academicians & $\begin{array}{l}\text { Some of them reported having anxiety, difficulty in staying } \\
\text { concentrated and easily lost motivation that affected their } \\
\text { academic research. }\end{array}$ \\
\hline
\end{tabular}




\begin{tabular}{|c|c|c|c|c|c|}
\hline 10. & Islam (2020) & India & Qualitative & Employee & $\begin{array}{l}\text { Working long hours and domestic responsibilities had made } \\
\text { participants experience disruption in psychological and mental } \\
\text { well-being. }\end{array}$ \\
\hline 11. & $\begin{array}{l}\text { Goldfarb et. } \\
\text { al. }(2021)\end{array}$ & Israel & Mixed methods & Employee (Autistic) & $\begin{array}{l}\text { When they transition to work from home, employees reported to } \\
\text { be having disruption in mental health and had a decline in work } \\
\text { satisfaction. }\end{array}$ \\
\hline 12. & $\begin{array}{l}\text { Molino et. al. } \\
(2020)\end{array}$ & Italy & Quantitative & Employees & $\begin{array}{l}\text { Employees had experienced techno-stress due to them spending } \\
\text { longer hours to finish their tasks on the computer. This shows } \\
\text { how technology has invaded their personal life. }\end{array}$ \\
\hline 13. & $\begin{array}{l}\text { Hallman et. } \\
\text { al. }(2021)\end{array}$ & Sweden & Quantitative & 484 Employees & $\begin{array}{l}\text { Working from home has allowed employees to have longer } \\
\text { duration of sleep which can benefit their well-being. }\end{array}$ \\
\hline 14. & $\begin{array}{l}\text { Kumar et. al. } \\
(2021)\end{array}$ & India & Quantitative & Employees & $\begin{array}{l}\text { Most professionals either from the public or private sectors show } \\
\text { symptoms of distress when working from home. }\end{array}$ \\
\hline 15. & $\begin{array}{l}\text { Marimuthu \& } \\
\text { Vasudevan } \\
(2020)\end{array}$ & Malaysia & Quantitative & 104 Employees & $\begin{array}{l}\text { The disruption in employees' well-being are found to be } \\
\text { interconnected with technical issues, distraction and multitasking } \\
\text { since it can cause pressure situation to them. }\end{array}$ \\
\hline
\end{tabular}

Table 9 Summary of Literature on Impact of Work from Home (WFH)

Theme 8: Impact in Work Environment

\begin{tabular}{|c|c|c|c|c|c|}
\hline No. & $\begin{array}{c}\text { Author } \\
\text { (year) }\end{array}$ & Country & Research Design & Sample/Population & Findings \\
\hline 1. & $\begin{array}{l}\text { Nur Afiqah } \\
\text { et. al. }(2020)\end{array}$ & Malaysia & Quantitative & Random & $\begin{array}{l}\text { Work from home has proven to give employees less distraction if } \\
\text { compared to the traditional office. They have much more freedom } \\
\text { in doing their work since there is a technological advancement } \\
\text { which makes it possible to do everything online. }\end{array}$ \\
\hline 2 . & $\begin{array}{l}\text { Sridhar \& } \\
\text { Bhattacharya } \\
(2020)\end{array}$ & India & Quantitative & Employees (IT companies) & $\begin{array}{l}\text { The job effectiveness of employees when working from home } \\
\text { was affected by household members and power cuts. }\end{array}$ \\
\hline 3. & $\begin{array}{l}\text { Yadav et. al. } \\
(2020)\end{array}$ & India & Quantitative & $\begin{array}{l}\text { Education institutes in Pune } \\
\text { City }\end{array}$ & $\begin{array}{l}\text { They often experience network issues and technical failures when } \\
\text { working from home. }\end{array}$ \\
\hline 4. & $\begin{array}{l}\text { Hasan et. al. } \\
(2020)\end{array}$ & Pakistan & Quantitative & Employees & $\begin{array}{l}\text { Employees that are in the rural areas were barely able to perform } \\
\text { work from home due to the lack of resources, internet coverage } \\
\text { and the nature of their work itself. }\end{array}$ \\
\hline
\end{tabular}




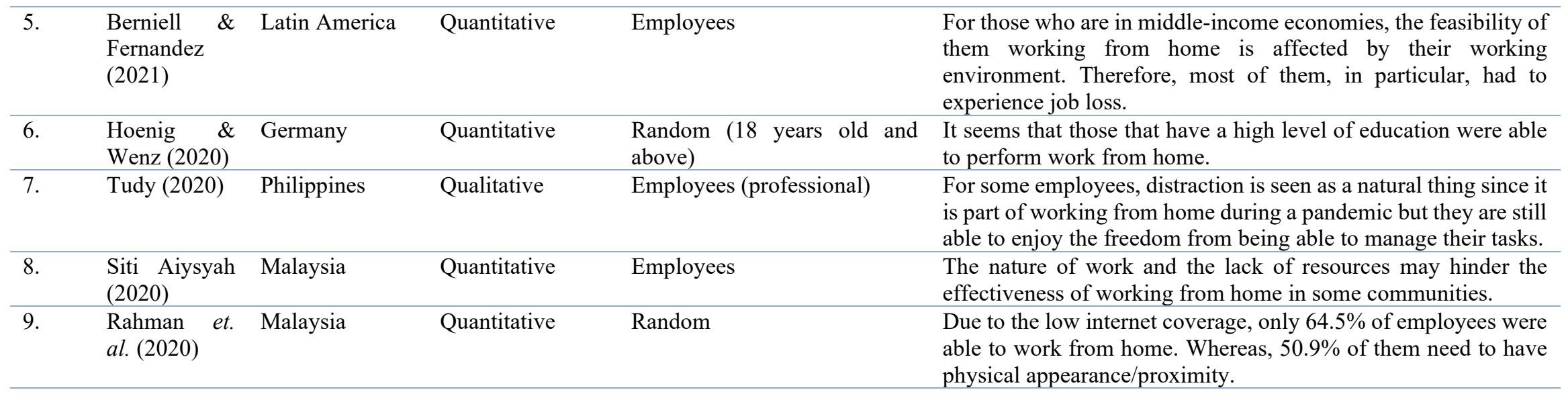

Table 10 Summary of Literature on Impact of Work from Home (WFH)

Theme 9: Impact in Work-life Conflict

\begin{tabular}{|c|c|c|c|c|c|}
\hline No. & $\begin{array}{l}\text { Author } \\
\text { (year) }\end{array}$ & Country & Research Design & Sample/Population & Findings \\
\hline 1. & $\begin{array}{l}\text { Couch et. al. } \\
(2020)\end{array}$ & - & - & Academicians & $\begin{array}{l}\text { There is a demand for multifaceted roles and it has not only } \\
\text { changed their experience in working from home but it also has } \\
\text { created conflict for them. }\end{array}$ \\
\hline 2. & $\begin{array}{l}\text { Arntz et. al. } \\
(2020)\end{array}$ & Germany & - & Employees & $\begin{array}{l}\text { The conflict that arises for working parents has the potential to be } \\
\text { resolved once childcare and facilities are once open again. }\end{array}$ \\
\hline
\end{tabular}


Table 11 Summary of Literature on Impact of Work from Home (WFH)

Theme 10: Impact on Work Productivity

\begin{tabular}{|c|c|c|c|c|c|}
\hline No. & $\begin{array}{c}\text { Author } \\
\text { (year) }\end{array}$ & Country & Research Design & Sample/Population & Findings \\
\hline 1. & $\begin{array}{l}\text { Wu \& Chen } \\
(2020)\end{array}$ & $\begin{array}{l}\text { United States of } \\
\text { America }\end{array}$ & Quantitative & $\begin{array}{l}\text { Educators } \quad \& \quad \text { Industrial } \\
\text { employees }\end{array}$ & $\begin{array}{l}\text { When there is a heavy workload experienced by employees when } \\
\text { working from home, their job productivity will decrease and the } \\
\text { reason for this is due to technical issues that they face. }\end{array}$ \\
\hline 2. & $\begin{array}{l}\text { Aum et. al. } \\
(2021)\end{array}$ & $\begin{array}{l}\text { South Korea \& } \\
\text { United } \\
\text { Kingdom }\end{array}$ & Quantitative & Employees & $\begin{array}{l}\text { The working arrangement itself (e.g. work from home) and } \\
\text { sickness made people less productive in their work. }\end{array}$ \\
\hline 3. & $\begin{array}{l}\text { Ramos \& } \\
\text { Prasetyo } \\
(2020)\end{array}$ & Philippines & Quantitative & Random & $\begin{array}{l}\text { Work from home has various factors that make it not feasible or } \\
\text { effective for some workers during the lockdown and these } \\
\text { somehow give an impact on their work productivity. }\end{array}$ \\
\hline 4. & $\begin{array}{l}\text { Chadee et. al. } \\
(2021)\end{array}$ & China & Quantitative & $\begin{array}{l}\text { Employees (mid-managerial in } \\
\text { hospitality industries) }\end{array}$ & $\begin{array}{l}\text { Even though employees can perform work from home during the } \\
\text { pandemic, they have trouble staying productive at work; which } \\
\text { makes them experience withdrawal and avoid work. }\end{array}$ \\
\hline 5. & $\begin{array}{l}\text { Rugayah et. } \\
\text { al. }(2020)\end{array}$ & Malaysia & Quantitative & Employees (administrative) & $\begin{array}{l}\text { Even though employees are satisfied in transitioning to work } \\
\text { from home, however, their quality of job does not present their } \\
\text { productivity. }\end{array}$ \\
\hline
\end{tabular}

\section{Theme 1: Working hours.}

The transition to work from home has a direct impact on workers' working hours, in particular, occupations that rely on physical appearances to complete their tasks or have a need to meet with clients face to face. When the restrictions were implemented, some found themselves in a state of work absenteeism and job loss. According to Shibata (2020), the decline in working hours was very much revolved around economic recession and stay-at-home order. When in the past, the reduction of working hours was unlikely related to job losses or absenteeism. It was part of a flexible working arrangement that was given to employees to make work remotely much easier (OECD, 2016). However, in our current situation, we were able to see how the external force can change and reap the benefits of working from home away from employees. 


\section{Theme 2: Employment relations.}

Employment relations can come from different perspectives or contexts, but it often revolves around the connection between employer and employees. With the implementation of working from home, the workers and employers are very much aware of the distance it can bring to the normal working environment. The distance itself can easily take away the trust and change one perception over another employee's efficiency (Jackowska \& Lauring, 2021). Even though technological advancement in our current era like virtual meetings has made it possible to retain communication between workers. It still could not dissolve this problem or issue when most of this work from home arrangement can take a long period of time in the world of work. It can only get a positive outcome if there is organizational support that endorses digitalization in the companies for remote working (Lee, 2021). Furthermore, being away from workers and employees also resulted in the lack of ad-hoc discussion which some may see as an importance to ensure proper planning and follow-up (Waizenegger et. al., 2020).

\section{Theme 3: Gender division.}

Work from home is a part of a flexible working arrangement and most of the implementation takes regards to help women in labor participation (ILO, 2020). However, these circumstances slightly change due to the closure of institutions and business operations during a lockdown. Most of the family members will be in the same household and upon doing these reviews, conflicts within gender division are often mentioned in the studies. According to Yaish et. al. (2021), it is hard to have a balanced gender division when most of the women take most of the housework responsibility and unpaid work on their own; this has led them to be more vulnerable to losing paid work hours than men. These issues and impacts however are not far from the problem that often arises when it comes to working from home. Arntz et. al. (2020) confirm that this mostly related to work or family conflict, which had been known to involve the working parents. Men are more prioritized in their male duties and work rather than their parental role (Ibarra et. al., 2020); it has something to do with the culture in the community as reported by Lim et. al. (2020) and Yaish et. al. (2021). The circumstances we are facing now does not help the women either; they lost the help from maid or nanny to ease their burden in domestic responsibilities which causing them to be more distressed (Berniell \& Fernandez, 2021; Casele \& Posel, 2021; Sridhar \& Sanjay, 2020; Joshi et. al., 2020; Meyer et. al., 2021; Bhattacharjee, 2020). This can also lead to burnout since they must balance work and family during that time (Feng \& Savani, 2020). But despite women taking most of the highlight in the disruption in gender division, Yerkes et. al. (2020) argue that fathers do share greater responsibilities on childcare and housework during the lockdown, but due to the lack of studies for this group, it is almost unidentifiable.

\section{Theme 4: Work-life balance.}

When employees start to bring work home, the concern is how can they balance both work and personal life without disrupting each other's domain? According to Kalliath \& Brough (2008), the work-life balance is an individual's multiple roles of non-work (family or personal) colliding with their working days. When working from home we can expect that this could happen for some employees. Therefore, as employees spend more time with screen-based meetings, workload, and tasks for their work; it also leads to more sedentary activities and less physical activity in their personal life (McDowell et. al., 2020; Fukushima et. al., 2021). This also proves by Pluut and Wonders (2020), in which they found employees who are more active in working from home are open to rising in blurred between work-life boundaries. Palumbo (2020) backed it up with his studies as public servants or civil service received negative impacts on work from home due to an increase in work-to-life conflicts. This, in turn, leads to work fatigue. Furthermore, Bhumika (2020) reported that women have more interference in personal 
life and work due to the lack of participative leadership in domestic care. This has led to the disruption of their well-being and affects their psychological behavior.

\section{Theme 5: Gender gaps/inequality.}

The gender gap is interconnected with work-life balance because women tend to devote themselves to domestic responsibilities, hence, causing their productivity and work satisfaction to be affected, unlike their partner. Feng \& Savani (2020) found that this does not usually happen before the pandemics force the major scale of work-from-home implementation. Now, inequality tends to happen to women as they experience job loss starting from February to April 2020 as recorded by Casale \& Posel (2021). This is caused by their vulnerability and commitment to domestic care more than men. International Labour Organization (2020) found it concerning to have women carry the burden in economic and social costs during the pandemic crisis; they suffer a job loss and reduction of working hours and carry a heavy workload of burden when at home; this, in turn, has the potential to erase gender equality that G20 achieved in the past (ILO, 2020).

\section{Theme 6: Job insecurity.}

Adams-Prassl et. al. (2020) claim that not every task can be performed at home, some are likely to suffer from the economic recession which causes self-employed workers in the United States of America and Germany to be at risk of being laid off. We need to understand this by looking from the perspective of the nature of their work. Those in the manufacturing or production companies rely more on physical appearances to manage their tasks and by transitioning to work from home, many had trouble complying. Furthermore, the closure of many companies during lockdown also added more to the risk of profit loss and liquidation; it can put employees' work positions at risk. Only those who are in permanent contracts or salaried employees are more secure from being furlough. Joshi et. al. (2020) found that many participants become stressed and concerned since their work is at stake due to financial constraints in their employing organizations. This finding has similar results with Prochazkac et. al. (2020), employees have seen their income loss due to the crisis in their company that pushes the organization to decrease job promotion.

\section{Theme 7: Well-being.}

When work from home becomes the alternative work arrangement, many researchers found that the psychological and mental health of employees is highly impacted. Limbers et. al. (2020) believe that this is due to parenting stress and maternal social relationships for working mothers that lack the intensity of physical activity. When in the past, work from home was quite known to improve workers' well-being because it gives them the flexibility to do their work in productive time (OECD, 2020). However, Anwar et. al. (2021) prove that work from home deprives employees of their growth opportunity and communications with their colleagues, which can contribute to their psychological state. It was then explained that technostress becomes a new illness as there are high workloads for individuals at home that pressure them to work diligently and longer, it directly causes invasion of technology in their private life (Molino et. al., 2020). Furthermore, work from home also causes sleep deprivation due to screen exposure and disrupts the sleep schedule (Prochazkac et. al., 2020). This work of literature shows how well-being can be affected if an individual has a hard time managing both work and private life.

\section{Theme 8: Work environment.}

The work environment has many important roles in our job productivity and performance and working from home is assumed to give more comfortability if compared to the traditional 
office. They have more freedom to work on their tasks in their own productive time and receive less distraction unlike in the central office (Afiqah et. al., 2020). But this could not be the same for working parents that have children especially below the age of 12 years old. The distraction is bound to happen whether they like it or not. Furthermore, it is not the only thing affecting employees' work environment at home, some have trouble properly doing their work at home due to the lack of internet coverage and lack of technological resources to perform it (Sridhar \& Bhattacharya, 2020; Yadav et. al.,2020) Therefore, those in the developing countries have been proactive in building better internet coverage and provide necessary initiatives to help employees to set up for work from home during the lockdown.

\section{Theme 9: Work to life conflict.}

The implementation of work from home could only mean that there will be a combination of work and family roles in one setting. Additionally, with school closures this has brought a radical change in the experience of working from home as many had to carry multi-faceted roles as employees, partners, mothers, and 'family manager' (Couch et. al., 2020). This has led to conflicts between professional, familial, and social roles. This issue is not uncommon since it has always been a topic of interest for researchers in the past. For example, according to Chandola et. al. (2004), the multi roles carried by most working parents may have its advantage in role enhancement, but this can also be a disadvantage since there will be role strain that may affect health and well-being.

\section{Theme 10: Work-productivity.}

The productivity of workers and employees is deemed important to set the quality of work and their performance. It is the most important aspect in any working organization whether in the public sector, private sector, or even self-employed. When working from home it can be an unusual atmosphere for workers that are not experienced or only done it just a couple of times. Therefore, the lockdown makes this transition a bit challenging for some. Wu and Chen (2020) found that working from home not only increases employees' workload, but they constantly lose productivity due to stress and pressure. This, later on, proved by Aum et. al. (2021) as they found that work from home in South Korea and the United Kingdom makes people less productive whether during their working time or not. However, productivity can be different among employees since some may be due to the workload or even the nature of their work; whereas some are from the technical issues they face when doing their job at home (Aum et. al., 2021).

In summary, the extraction of data from the works of the literature shows that there is a more negative impact of work from home to the employees, employer, and even the companies/organization. We would be able to see that work from home can cause the reduction of working hours and it was not necessarily because of the workers right to shorten it but to the fact that it was caused by job losses and absenteeism (Berniell \& Fernandez, 2021; Forsythe et. al., 2020; Shibata, 2020; Alipour et. al., 2021; Casele \& Posel, 2021; Hoenig \& Wenz, 2020); employment relations also seem to be affected by this as the distance creates gaps that may put doubt and lack of trust between employer and employees (Osman et. al., 2020; Anwar et. al., 2021; Prihadi et. al., 2021; Waizenegger et. al., 2020; Malik et. al., 2020; Jackowska \& Lauring, 2021); the gender division does not show positivity for women as they take most of the leadership at home (Berniell \& Fernandez, 2021; Lim et. al., 2021; Casele \& Posel, 2021; Limbers et. al., 2020; Bhumika, 2020; Joshi et. al., 2020; Feng \& Savani, 2020; Yaish et. al., 2021; Meyer et. al., 2021; Yerkes et. al., 2020; Bhattacharjee, 2020). This pandemic also shows negative signs for employees as they experience more open stress from both work and personal life, which can cause disruption in their work-life balance (Marimuthu, 2020; Anwar et. al., 2021; Kumar et. al., 2021; Hallman et. al., 2021; Molino et. al., 2020; Chadee et. al., 2021; 
Goldfarb et. al., 2021; Meyer et. al., 2021; Islam, 2020; McDowell et. al., 2020; Pluut \& Wonders, 2020; Akyildiz \& Durna, 2020; Ghogare, 2020; Sheikh et. al., 2020; Majumdar et. al., 2020; Malik et. al., 2020; Kniffin et. al., 2021; Lee, 2021; Palumbo, 2020; Bhumika, 2020; Limbers et. al., 2020). Furthermore, with gender division becoming unbalanced and one gender is more vulnerable for job losses and reduction in income, this has led to gender inequality or gaps (Hasan et. al., 2020; Berniell \& Fernandez, 2021; Casele \& Posel, 2021; Feng \& Savani, 2020; Yaish et. al., 2021; Meyer et. al., 2021; Yerkes et. al., 2020).

The pandemic also has brought job insecurity into light as this was rarely the problem before and it made employees worry about their position, in particular, for those who do not have a permanent contract (Tumin, 2020; Prochazkac et. al., 2020; Joshi et. al., 2020; Malik et. al., 2020; Berniell \& Fernandez, 2021). Well-being also becomes the impact in working from home as they experience deterioration in both psychology and mental health (Limbers et. al., 2020; Bhumika, 2020; Lee, 2021; Kniffin et. al., 2021; Malik et. al., 2020; Majumdar et. al., 2020; Sheikh, 2020; Akyildiz \& Durna, 2020; McDowell et. al., 2020; Islam, 2020; Meyer et. al., 2021; Goldfarb et. al., 2021; Chadee et. al., 2021; Molino et. al., 2020; Hallman et. al., 2021; Kumar et. al., 2021; Anwar et. al., 2021; Osman et. al., 2020; Marimuthu \& Vasudevan, 2020). The lockdown has shown that the working environment brought several challenges to employees that some may find it hard to overcome or not even feasible for them to work from home (Hashim et. al., 2020; Rahman et. al., 2020; Osman et. al., 2020; Wu \& Chen, 2020; Schall et. al., 2020; Prochazkac et. al., 2020; Waizenneger et. al., 2020; Shibata, 2020; Berniell \& Fernandez, 2021; Hasan et. al., 2020). Work from home has also caused the issue of multiroles conflict due to heavy responsibilities in one of the genders, in particular, women (Berniell \& Fernandez, 2021; Casele \& Posel, 2021; Bhumika, 2020; Palumbo, 2020; Ghogare, 2020; Couch et. al., 2020; Meyer et. al., 2021; Yerkes et. al., 2020; Arntz et. al., 2020). Lastly, work from home has made a significant impact on workers' job productivity (Hashim et. al., 2020; Osman et. al., 2020; Wu \& Chen; 2020; Yadav et. al., 2020; Feng \& Savani, 2020; Ramos \& Prasetyo, 2020; Aum et. al., 2021; Berniell \& Fernandez, 2021).

\section{FUTURE RESEARCH AGENDA}

While looking through the collected literature review several proposed ideas can be considered in future research. There is still a lack of population that represents unmarried respondents, self-employed, and single parents, hence, in future research, the study can use these limitations to use this as a population or sample. It will give this trend of research a more holistic approach and representation across any group or age. Other than that, there is a suggestion for a qualitative approach to be used in future research, due to the fact that most of this literature uses quantitative data. The quantitative data in this current literature may help in setting up a more valid follow-up by taking a much in-depth approach to which it can offer reliable or reproducible information through the change of times. Roslinah et. al. (2020) suggested expanding the sampling and statistical testing to further explain the relationship between demographics factors and work from home (Roslinah et. al., 2020). They believe other variables such as workload, work environment, and gender inequality can also be researched further in a Malaysian context.

\section{CONCLUSION}

To take the first step into understanding the situation of work from home as the new working arrangement during the pandemic, current knowledge serves as additional information to guide researchers to better understand their background topics. The selected articles have helped in identifying several impacts regarding work from home, and that is the decline in working hours, 
disruption in work-life balance and well-being, and change in the communication between employees. However, the limitations caused by the limited budget had forced researchers to only focus on an open-access paper and remove potential paid-paper to be reviewed. Nevertheless, if there is a similar approach to study the topics of work from home, they can consider this.

\section{ACKNOWLEDGMENT}

This study is funded by Universiti Malaysia Sabah under the Special Research Scheme Grant SDK0150-2020.

\section{REFERENCES}

Adams-Prassl, A., Boneva, T., Golina, M., \& Rauh, C. (2020). Inequality In the Impact of The Coronavirus Shock: Evidence from Real-Time Surveys. Journal of Public Economics (189) https://doi.org/10.1016/j.jpubeco.2020.104245

Anwar, A., Mui Hung Kee, D., Salman, A., \& Jabeen, G. (2021). Impact Of Covid-19 Social Media News on Employee Behavior: The Mediating Role of Psychological Well-being and Depression. Asian Education and Development Studies. Emerald Publishing Limited. DOI 10.1108/AEDS-07-2020-0159

Akyildiz D, D. S. (2021). Determining The Research Status and Coronavirus Anxiety Scores of Academics During The Flexible Working Arrangements Initiated After The Covid-19 Pandemic. Journal of Taibah University Medical Sciences. https://doi.org/10.1016/j.jtumed.2021.01.005

Akash, D.D. \& Shreya, T. (2020). Analyzing the Sentiments towards Work-From-Home Experience during COVID-19 Pandemic - Letter from Academia. Journal of Innovation Management. www.open-jim.org, 8(1), 13-19. DOI: https://doi.org/10.24840/2183$0606 \_008.001 \_003$

Alipour, J., Fadinger, H., \& Schymik, J. (2021). My Home Is My Castle - The Benefits of Working from Home During A Pandemic Crisis. Journal of Public Economics (196). https://doi.org/10.1016/j.jpubeco.2021.104373

Arntz, M., Yahmed, S. B., \& Berlingieri, F. (2020). Working from Home and COVID-19: The Chances and Risks for Gender Gaps. Labour Market. DOI: 10.1007/s10272-020-09385

Auma, S., (Tim) Lee, S. Y., \& Shin, Y. (2021). Inequality Of Fear and Self-quarantine: Is There A Trade-off Between Gdp And Public Health? Journal of Public Economics (194). https://doi.org/10.1016/j.jpubeco.2020.104354

Bhumika (2020). Challenges For Work-life Balance During Covid-19 Induced Nationwide Lockdown: Exploring Gender Difference in Emotional Exhaustion in The Indian Setting. Gender in Management: An International Journal. Vol. 35 No. 7/8. pp. 705-718. Emerald Publishing Limited. DOI 10.1108/GM-06-2020-0163

Brynjolfsson, E. et. al. (2020). Nber Working Paper Series. National Bureau of Economic Research.

Berniell, L. \& Fernandez, D. (2021). Jobs’ Amenability Is Not Enough: The Role of Household Inputs For Safe Work Under Social Distancing In Latin American Cities. World Development 140. https://doi.org/10.1016/j.worlddev.2020.105247

Baker, M.G. (2020). Characterizing Occupations That Cannot Work 1 From Home: A Means to Identify Susceptible Worker 2 Groups During The Covid-19 Pandemic. medRxiv Publication. https://doi.org/10.1101/2020.03.21.20031336 
Bhattacharjee, S. (2020). 'Work From Home' As an Alternative To Daily Commuting For Working Women. Human Geographies - Journal of Studies and Research in Human Geography. Vol. 14, No. 2. DOI:10.5719/hgeo.2020.142.5

Casale, D. \& Posel, D. (2021). Gender Inequality and The Covid-19 Crisis: Evidence from A Large National Survey During South Africa's Lockdown. Research in Social Stratification and Mobility (71). https://doi.org/10.1016/j.rssm.2020.100569

Couch, D.L., O'Sullivan, B. \& Malatzky, C. (2020). What Covid-19 Could Mean for The Future Of "Work from Home": The Provocations Of Three Women In The Academy. Gender Work Organ. 28(S1):266-275. DOI: 10.1111/gwao.12548

Chadee, D., Ren, S., \& Tang, G. (2021). Is Digital Technology The Magic Bullet For Performing Work At Home? Lessons Learned for Post Covid-19 Recovery in Hospitality Management. International Journal of Hospitality Management (92). https://doi.org/10.1016/j.ijhm.2020.102718

McDowell, C.P. et. al. (2020). Working From Home and Job Loss Due to the COVID-19 Pandemic Are Associated with Greater Time in Sedentary Behaviors. Front. Public Health 8:597619. DOI: 10.3389/fpubh.2020.597619

Chandola, T. et. al. (2004). Does Conflict Between Home and Work Explain The Effect of Multiple Roles on Mental Health? A Comparative Study of Finland, Japan and UK. International Journal of Epidemiology. Vol 33, Issue 4. Pages 884-893, https://doi.org/10.1093/ije/dyh155

Moher, D. et. al. (2009). Preferred Reporting Items for Systematic Reviews and Meta-Analyses: The PRISMA Statement. BMJ. doi: https://doi.org/10.1136/bmj.b2535

Fukushima, N. et. al. (2021). Associations Of Working from Home with Occupational Physical Activity and Sedentary Behavior Under The Covid-19 Pandemic. Journal of Occupational Health. https://doi.org/10.1002/1348-9585.12212

Forsythe, E., Kahnb, L.B., Lange, F. \& Wiczer, D. (2020). Labor Demand in The Time of Covid-19: Evidence from Vacancy Postings And Ui Claims. Journal of Public Economics (189). https://doi.org/10.1016/j.jpubeco.2020.104238

Feng, Z. \& Savani, K. (2020). Covid-19 Created A Gender Gap in Perceived Work Productivity and Job Satisfaction: Implications For Dual-career Parents Working From Home. Gender in Management: An International Journal. Vol. 35 No. 7/8, pp. 719-736. DOI 10.1108/GM-07-2020-0202

Goldfarb, Y., Gal, E. \& Golan, O. (2021). Implications of Employment Changes Caused by COVID-19 on Mental Health and Work-Related Psychological Need Satisfaction of Autistic Employees: A Mixed-Methods Longitudinal Study. Journal of Autism and Developmental Disorders. https://doi.org/10.1007/s10803-021-04902-3

Hallman et al. (2021). Working From Home During The Covid-19 Outbreak In Sweden: Effects On 24-h Timeuse In-Office Workers. BMC Public Health. https://doi.org/10.1186/s12889-021-10582-6

Hoenig, K. \& Wenz, S.E. (2021) Education, health behavior, and working conditions during the pandemic: evidence from a German sample. European Societies. 23:sup1, S275S288, DOI: 10.1080/14616696.2020.1824004

Pluut, H. \& Wonders, J. (2020). Not Able to Lead a Healthy Life When You Need It the Most: Dual Role of Lifestyle Behaviors in the Association of Blurred Work-Life Boundaries With Well-Being. Front. Psychol. 11:607294. Doi: 10.3389/fpsyg.2020.607294

Thomas, J. \& Harden, A. (2008). Methods for the Thematic Synthesis of Qualitative Research in Systematic Review. BMC.

Hasan, S.M., Rehman, A., \& Zhang, W. (2020). Who Can Work And Study From Home In Pakistan: Evidence From A 2018-19 Nationwide Household Survey. World Development 138. https://doi.org/10.1016/j.worlddev.2020.105197 
Ibarra, H., Gillard, J. \& Chamorro-Premuzic, T.. (2020). Why WFH Isn't Necessarily Good for Women. Retrieved from https://hbr.org/2020/07/why-wfh-isnt-necessarily-good-forwomen on 23 June 2021.

International Labour Organization. (2020). The Impact of the Covid-19 Pandemic on Jobs and Incomes in G20 Economies. Saudi Arabia.

Islam, A. (2020). “Two Hours Extra For Working From Home”: Reporting On Gender, Space, And Time From The Covid-field Of Delhi, India. Gender Work Organ 1-10. DOI: 10.1111/gwao.12617

International Labour Organization. (2021). COVID-19 and The World of Work. Retrieved from https://www.ilo.org/global/topics/coronavirus/lang--en/index.htm on 1 April 2021.

Jackowska, M. \& Lauring, J. (2021). What Are The Effects Of Working Away From The Workplace Compared To Using Technology While Being At The Workplace? Assessing Work Context and Personal Context in A Global Virtual Setting. Journal of International Management (27). https://doi.org/10.1016/j.intman.2021.100826

Joshi, S.G. et. al. (2020). Challenges Faced by Working Population During Lockdown in Response to Corona Virus Outbreak. Indian Journal of Forensic Medicine \& Toxicology. Vol. 14, No. 4.

Kalliath, T. \& Brough, P. (2008). Work-life Balance: A Review of The Meaning Of The Balance Construct. Journal of Management \& Organization. Vol. 14 (03). DOI:10.5172/jmo.837.14.3.323

Kniffin, K.M et. al., (2020). COVID-19 and the Workplace: Implications, Issues, and Insights for Future Research and Action. American Psychologist. Vol. 76, No. 1, 63-77. ISSN: 0003-066X. http://dx.doi.org/10.1037/amp0000716

Kumar, P., Kumar, N., Aggarwal, P., \& A.L. Yeap, J.. (2021). Working In Lockdown: The Relationship Between Covid-19 Induced Work Stressors, Job Performance, Distress, And Life Satisfaction. Current Psychology. Springer Pub. https://doi.org/10.1007/s12144021-01567-0

Kraus, S. et. al. (2020). The Art of Crafting a Systematic Literature Review in Entrepreneurship Research. International Entrepreneurship and Management Journal. Springer.

Limbers, C.A., McCollum, C., \& Greenwood, E. (2020). Physical Activity Moderates The Association Between Parenting Stress And Quality Of Life In Working Mothers During The Covid-19 Pandemic. Mental Health and Physical Activity (19). https://doi.org/10.1016/j.mhpa.2020.100358

Lee, H. (2021). Changes In Workplace Practices During The Covid-19 Pandemic: The Roles Of Emotion, Psychological Safety, And Organisation Support. Emerald Publishing Limited. Doi 10.1108/Joepp-06-2020-0104

Shamseer, L. et. al. (2009). Preferred Reporting Items For Systematic Review And Metaanalysis Protocols (Prisma-p) 2015: Elaboration And Explanation. BMJ 2015.349:g7647. DOI: 10.1136/bmj.g7647

Lim, Y. et. al. (2020). Men and Women's Different Dreams on the Future of the Gendered Division of Paid Work and Household Work after COVID-19 in South Korea. Research in Social Stratification and Mobility (69). https://doi.org/10.1016/j.rssm.2020.100544

Malik, A., Sinha, S., \& Goel, S.. (2020). The "Screening of You and Me: Effects of COVID19 on Counterproductive Work Behaviors. IEEE Engineering Management Review. VOL. 48, NO. 3. DOI 10.1109/EMR.2020.3010323

Meyer, B., Zill, A., Dilba, D., Gerlach, R. \& Schumann, S. (2021). Employee Psychological Well-being During The Covid-19 Pandemic In Germany: A Longitudinal Study Of Demands, Resources, And Exhaustion. International Journal of Psychology. DOI: 10.1002/ijop.12743 
McDowell, C.P. et. al. (2020). Working from Home and Job Loss Due to The COVID-19 Pandemic are Associated with Greater Time in Sedentary Behaviour. Front. Public Health.

Molino, M. et. al. (2020). Wellbeing Costs of Technology Use during Covid-19 Remote Working: An Investigation Using the Italian Translation of the Technostress Creators Scale. Sustainability. 12, 5911; doi:10.3390/su12155911

Majumdar, P., Biswas, A., \& Sahu, S. (2020). Covid-19 Pandemic and Lockdown: Cause Of Sleep Disruption, Depression, Somatic Pain, And Increased Screen Exposure Of Office Workers And Students Of India. Chronobiology International. 37:8, 1191-1200, DOI: $10.1080 / 07420528.2020 .1786107$

OECD. (2020). How's life in Finland? Retrieved from https://doi.org/10.1787/9870c393-en on 24 June 2021.

Purwanto, A. et. al. (2020). Impact of Work from Home (WFH) on Indonesian Teachers Performance During the Covid-19 Pandemic: An Exploratory Study. International Journal of Advanced Science and Technology. Vol. 29, No. 5, (2020), pp. 6235 - 6244.

Pak, A. et. al. (2020). Economic Consequences of the COVID-19 Outbreak: the Need for Epidemic Preparedness. Front. Public Health. https://doi.org/10.3389/fpubh.2020.00241

Pluut, H. \& Wonders, J. (2020). Not Able to Lead a Healthy Life When You Need It The Most: Dual Role of Lifestyle Behaviours in The Association of Blurred Work-Life Boundaries with Well-Being. Front. Psychology.

Prochazka, J. (2020). Data On Work-related Consequences of Covid-19 Pandemic For Employees Across Europe. Data in Brief (32). https://doi.org/10.1016/j.dib.2020.106174

Prihadi, K.D. et. al. (2021). Efficacy Of Working from Home Among Urban Professionals In Malaysia During The Pandemic: The Robust Predictive Role Of Mattering. International Journal of Public Health Science (IJPHS) Vol. 10, No. 1, March 2021, pp. 215 220. DOI: $10.11591 /$ is.v10i1.20736

Palumbo, R. (2020). Let Me Go to The Office! An Investigation into The Side Effects Of Working From Home On Work-life Balance. International Journal of Public Sector Management. Vol. 33 No. 6/7, pp. 771-790. Emerald Publishing Limited. DOI 10.1108/IJPSM-06-2020-0150

Ramos, J. P. \& Prasetyo, Y. T. (2020). The Impact of Work-Home Arrangement on the Productivity of Employees during COVID-19 Pandemic in the Philippines: A Structural Equation Modelling Approach. ICIBE. https://doi.org/10.1145/3429551.3429568

Ranney, M. L., Griffeth, V., \& Jha, A. K. (2020). Critical Supply Shortages - The Need for Ventilators and Personal Protective Equipment during the Covid-19 Pandemic. Journal of Medicine. DOI: 10.1056/NEJMp2006141

Roslinah M. et. al. (2020). Characteristics of Workers and Their Preferences to Work from Home (WFH). Asian Journal of Research in Business and Management. Vol. 2, No. 4.

Saat, G. \& C. Wyai, G. L. (2015). Investigating a Telecenter Contribution to Community Economic Development: An Experience of Buayan, Sabah, Malaysia. Jurnal Komunikasi Borneo Edisi Khas (Konvokesyen ke-17 UMS).

Schall, C., Brooke, V., Rounds, R. \& Lynch, A. (2020). The Resiliency Of Employees With Intellectual And Developmental Disabilities During The Covid-19 Pandemic And Economic Shutdown: A Retrospective Review Of Employment Files. Journal of Vocational Rehabilitation 54; 15-24 DOI:10.3233/JVR-201113

Savić, D. (2020). COVID-19 and Work from Home: Digital Transformation of the Workforce. TGJ Volume 16, Number 2.

Snyder, H. (2019). Literature Review as a Research Methodology: An Overview and Guidelines. Journal of Business Research. Elsevier. https://doi.org/10.1016/j.jbusres.2019.07.039 
Shibata, I. (2020). The Distributional Impact of Recessions: The Global Financial Crisis And The Covid-19 Pandemic Recession. Journal of Economics and Business. https://doi.org/10.1016/j.jeconbus.2020.105971

Sheikh, M. K., Chaudahry, N. \& Ghogare, A. (2020). Depression in Teachers Due to Cyberbullying Who are Working in COVID-19 Pandemic: A Cross-Sectional Study. International Journal of Current Research and Review. DOI: http://dx.doi.org/10.31782/IJCRR.2020.122015

Sridhar, V. \& Bhattacharya, S. (2020). Significant Household Factors That Influence An It Employees' Job Effectiveness While On Work From Home. International Journal of Innovation Science. Vol. 13 No. 1, pp. 105-117. Emerald Publishing Limited. DOI 10.1108/IJIS-09-2020-0171

Tudy, R. A. (2021). From The Corporate World to Freelancing: The Phenomenon Of Working From Home In The Philippines. Community, Work \& Family. 24:1, 77-92, DOI: 10.1080/13668803.2020.1809994

$\mathrm{Wu}, \mathrm{H}$. \& Chen, Y. (2020). The Impact of Work from Home (WFH) on Workload and Productivity in Terms of Different Tasks and Occupations. HCII. LNCS 12427, pp. 693706, 2020. https://doi.org/10.1007/978-3-030-60152-2_52

Waizenegger, L., McKenna, B., Cai, W. \& Bendz, T. (2020) An affordance perspective of team collaboration and enforced working from home during COVID-19. European Journal of Information Systems. 29:4, 429-442, DOI: 10.1080/0960085X.2020.1800417

World Health Organization. (2021). WHO Coronavirus (COVID-19) Dashboard. Retrieved from https://covid19.who.int/ on 1 April 2021.

Xiao, Y. \& Watson, M. (2017). Guidance on Conducting a Systematic Literature Review. Journal of Planning Education and Research. Sage Journal. https://doi.org/10.1177/0739456X17723971

Yaish, M., Mandel, H., \& Kristal, T. (2021). Has The Economic Lockdown Following The Covid-19 Pandemic Changed The Gender Division Of Labor In Israel? Gender \& Society. Sage Publication. Doi: 10.1177/08912432211001297

Yadav, P. et. al. (2020). Opportunities and Obstacles Faced During Work From Home in Teaching Faculties. Indian Journal of Forensic Medicine \& Toxicology. Vol. 14, No. 4.

Yasenov, V.. (2020). Who Can Work from Home? Institute of Labor Economics. IZA DP No. 13197.

Yerkes, A. SCH, Besamusca, K., Remery, V., et al. (2020) 'intelligent' Lockdown, Intelligent Effects? Results From A Survey On Gender (In)Equality In Paid Work, The Division Of Childcare And Household Work, And Quality Of Life Among Parents In The Netherlands During The Covid-19 Lockdown. PLoS ONE 15(11): e0242249. https://doi.org/10.1371/journal.pone.0242249 